\title{
Sanctioned countries in the global COVID-19 vaccination campaign: the forgotten $70 \%$
}

\author{
Karl Blanchet ${ }^{1,2}$, Grégoire Mallard ${ }^{3^{*}} \mathbb{D}$, Erica Moret ${ }^{3}$ and Jin Sun ${ }^{3}$
}

\begin{abstract}
COVAX, the global initiative on COVID-19 vaccines, has set the target of achieving a COVID-19 vaccination coverage of up to $30 \%$ of the population of 135 countries in 2 years. Here, we argue that COVAX should anticipate important and unforeseen challenges with regard to sanctioned countries. For those, COVAX needs to provide a higher percentage of the vaccines. Otherwise, the problems of vaccination will linger, risking the advent of new variants and preventing an effective global response in reigning the pandemic under control.
\end{abstract}

\section{Background}

COVAX, the global initiative on COVID-19 vaccines, has set the target of achieving a COVID-19 vaccination coverage of up to $30 \%$ [1] of the population of 135 countries in 2 years [2], with advance commitment to ensure access for 92 low- and middle-income countries (LMICs) [3]. This appears to be an ambitious and welcome objective.

Today, COVAX faces criticism mostly for the delays experienced by the implementation of its vaccination program. Indeed, as UNICEF shows [2], COVAX has shipped up to 68.8 million doses in 81 of the 92 LMICs, indicating delivery of only $3.8 \%$ of the promised 1.8 billion doses. Till now, eleven LMICs have not received any doses from COVAX. The main reasons for such a failure are however external to COVAX, and related to supply side issues like over-procurement by high income countries [4], or vaccine and vaccine material export restrictions imposed by high-income countries (HICs) like the US [5], leaving few stocks for LMICs. As the vaccination rates in HICs sits at about 40\% [6], there is reason to be hopeful that COVAX will be able to support LMICs in time.

*Correspondence: gregoire.mallard@graduateinstitute.ch

${ }^{3}$ Graduate Institute of International and Development Studies, Geneva, Switzerland

Full list of author information is available at the end of the article
Here, we argue that COVAX should anticipate additional challenges with regard to sanctioned countries. Currently, the UN, US and EU and others impose sanctions on over 20 countries around the world. While some of these sanctions are highly targeted in nature (such as arms embargoes, travel bans and individual asset freezes), and thus unlikely to influence certain countries' access to the vaccine, others represent de-facto comprehensive sanctions regimes, whose return results from the multiplying effect of overlapping sanctions regimes (sometimes alongside counterterrorism and anti-moneylaundering regulations), the adoption of broad sectoral sanctions (including those on finance and energy sectors in a dozen of countries) and the growing reluctance seen in the international banking sector to service transactions to so-called "high-risk" countries (known as over-compliance or 'de-risking') even for vaccine procurement.

While COVAX assumes that all LMICs will be able to procure $70 \%$ of the remaining doses, it has thus ignored the three specific difficulties that sanctioned countries run into when they seek to procure such type of goods. First, COVAX may experience problems when delivering the vaccine to sanctioned countries, such as Iran, North Korea, Syria, Venezuela, Afghanistan and Myanmar, due to hindered access to goods and services including temperature-controlled equipment, fuel, software, insurance or logistics operators. Relatedly, COVAX may not be able to deliver or administer vaccines to certain groups within original author(s) and the source, provide a link to the Creative Commons licence, and indicate if changes were made. The images or other third party material in this article are included in the article's Creative Commons licence, unless indicated otherwise in a credit line to the material. If material is not included in the article's Creative Commons licence and your intended use is not permitted by statutory regulation or exceeds the permitted use, you will need to obtain permission directly from the copyright holder. To view a copy of this licence, visit http://creativecommons.org/licenses/by/4.0/. The Creative Commons Public Domain Dedication waiver (http://creativecommons.org/publicdomain/zero/1.0/) applies to the data made available in this article, unless otherwise stated in a credit line to the data. 
de-risked countries, such as members of designated terrorist organisations (like Hezbollah) and other non-state armed groups.

Second, most sanctioned countries are not in a position to procure the remaining $70 \%$ of the COVID vaccines. Exporters or their banks may not authorize the transactions with them, again due to de-risking. After a wave of heavy sanctions enforcement actions by the US Treasury, seeing global banks paying fines entering into the billions of US dollars, all global banks increasingly avoid any transactions with US-sanctioned countries, like Iran and Venezuela [7]. UNICEF data [8] shows that while non-sanctioned countries directly purchase from multiple suppliers, global pharmaceutical companies declined the sales to sanctioned countries: none of them signed a supply agreement with Syria, Afghanistan, North Korea, Venezuela or Iran, and only one supplied to Myanmar but only for $25 \%$ of the population.

Third, bilateral donations, sometimes described as "vaccine diplomacy", have been delivered to some sanctioned countries by donors. It may make the impression in the international community that COVAX should concentrate on servicing the non-sanctioned developing countries and leave the delivery of vaccines to sanctioned countries to big powers. UNICEF data (Table 1) indicates that major economies, such as China, India, the US, Japan, Russia, and France are active in bilateral donations to specific countries, but the recipients are not those in most urgent humanitarian need.

\section{Conclusion}

Because of these three reasons, we estimate that in 2 years, with COVAX setting a target of procuring $30 \%$ of the needed vaccines in LMICs, about 60 to $70 \%$ of the adult population in the non-sanctioned developing countries could be vaccinated, but that less than $20 \%$ of the total adult population will be vaccinated in

Table 1 Covid-19 vaccine donation chart [9]

\begin{tabular}{llrlll}
\hline Donors & \# (million) & $\%$ & Recipients & \# (million) & Source \\
\hline China (C) & 23.97 & 38.9 & Pakistan & 4 & C, U \\
India (I) & 8.88 & 14.4 & China Taipei & 3.74 & J, U \\
US (U) & 8.51 & 13.8 & Bangladesh & 3.2 & C, I, U \\
Japan (J) & 8.37 & 13.6 & Nepal & 2.9 & C, I \\
Switzerland & 4 & 6.5 & Myanmar & 2.2 & C, I \\
MTN Group & 1.76 & 2.9 & Cambodia & 2.2 & C \\
Australia & 1.11 & 1.8 & Laos & 1.6 & C \\
Russia & 1.04 & 1.7 & Afghanistan & 1.6 & C, I \\
France & 0.82 & 1.3 & Sri Lanka & 1.6 & C, I \\
Total & 61.6 & 100.0 & & 39.6 & \\
\hline
\end{tabular}

the sanctioned developing world. We thus urge COVAX to rethink its targets and set two different kinds of programmes depending on whether LMICs face risks of financial exclusion because of sanctions. For those, COVAX needs to provide a higher percentage of the vaccines. Otherwise, the problems of vaccination will linger, risking the advent of new variants and preventing an effective global response in reigning the pandemic under control.

\section{Abbreviations \\ COVAX: COVID-19 vaccines global access initiative; HICs: High-income countries; LMICs: LoW- and middle-income countries; UNICEF: UN Children Foundation; WHO: World Health Organization.}

\section{Authors' contributions}

All authors contributed equally to writing, editing, refining and improving the document as well as all literature searching. All authors read and approved the final manuscript.

\section{Funding}

This publication is directly based on a project headed by Grégoire Mallard that received funding from the European Research Council under the European Union's Horizon 2020 research and innovation programme (Grant Agreement PROSANCT,'Bombs, Banks and Sanctions' Project 716216). Support also came from the Swiss Network for International Studies (SNIS).

\section{Availability of data and materials}

Data are available upon reasonable request. Data underlying this publication are available upon request to correspondence, UNICEF Covid-19 vaccine market dashboard: https://www.unicef.org/supply/covid-19-vaccine-marketdashboard, and, Bloomberg COVID vaccine tracker: https://www.bloomberg. com/graphics/covid-vaccine-tracker-global-distribution/.

\section{Declarations}

Ethical approval and consent to participate

Ethics approval was granted by the Ethics Committee of the Graduate Institute of International and Development Studies on the ERC Grant Project 716216, covering all countries in this publication.

Consent for publication

Not applicable.

\section{Competing interests}

The authors have no competing interests to declare.

\section{Author details}

${ }^{1}$ Geneva Centre of Humanitarian Studies, Geneva, Switzerland. ${ }^{2}$ Faculty of Medicine, University of Geneva, Geneva, Switzerland. ${ }^{3}$ Graduate Institute of International and Development Studies, Geneva, Switzerland.

Received: 6 Auqust 2021 Accepted: 6 September 2021

Published online: 17 September 2021

References

1. WHO. 27 May 2021 Joint Statement of Gavi, the Vaccine Alliance, UNICEF (UN Children Foundation), the Coalition for Epidemic Preparedness Innovations (CEPI), and the World Health Organization (WHO), 2021. https://www.who.int/news/item/27-05-2021-covax-joint-statement-callto-action-to-equip-covax-to-deliver-2-billion-doses-in-2021. Accessed 8 July 2021. 
2. UNICEF Covid-19 vaccine market dashboard. Delivery, COVAX deliveries https://www.unicef.org/supply/covid-19-vaccine-market-dashboard. Accessed 8 July 2021

3. GAVI. 92 low- and middle-income economies eligible to get access to COVID-19 vaccines through Gavi COVAX AMC (Advance Market Commitment), 2020. https://www.gavi.org/news/media-room/92-low-middleincome-economies-eligible-access-covid-19-vaccines-gavi-covax-amc. Accessed 8 July 2021

4. Reuters. Amnesty: rich countries have bought too many COVID-19 vaccines, Dec 09, 2020. https://www.reuters.com/article/health-coronavirusvaccines-idINKBN28J1BY. Accessed 8 July 2021.

5. US Presidential Executive Orders (EO) 13962 and 13987.

6. Bloomberg. Bloomberg COVID vaccine tracker, 2021. https://www.bloom berg.com/graphics/covid-vaccine-tracker-global-distribution/: Accessed 8 July 2021.

7. Reuters. Venezuela payment to COVAX received after funds blocked-GAVI, July 9, 2021. https://www.reuters.com/world/americas/venezuela-payme nt-covax-received-after-funds-blocked-gavi-2021-07-08/: Accessed 8 July 2021. Reuters. Iran blames U.S. sanctions for vaccine payment problems, Nov 13, 2020. https://www.reuters.com/article/us-health-coronavirusiran-idUSKBN27T26H: Accessed 8 July 2021.

8. UNICEF Covid-19 vaccine market dashboard. Agreements, Country/ group. https://www.unicef.org/supply/covid-19-vaccine-market-dashb oard. Accessed 8 July 2021.

9. UNICEF Covid-19 vaccine market dashboard. Delivery, Vaccine Donation. https://www.unicef.org/supply/covid-19-vaccine-market-dashboard. Accessed 11 July 2021. Note: MTN Group is a private company with leading telecom services in many African countries.

\section{Publisher's Note}

Springer Nature remains neutral with regard to jurisdictional claims in published maps and institutional affiliations.
Ready to submit your research? Choose BMC and benefit from:

- fast, convenient online submission

- thorough peer review by experienced researchers in your field

- rapid publication on acceptance

- support for research data, including large and complex data types

- gold Open Access which fosters wider collaboration and increased citations

- maximum visibility for your research: over 100M website views per year

At BMC, research is always in progress.

Learn more biomedcentral.com/submissions 